\title{
Community Based Tourism: A Correlation Between Knowledge and Participation in Mountain Based Destination
}

\author{
F. Rahmafitria, G. R. Nurazizah \\ Management of Resort and Leisure Study Program, Universitas Pendidikan Indonesia \\ Bandung, INDONESIA \\ rahmafitria@upi.edu
}

\begin{abstract}
Lots of community empowerment programs in tourism development has been done in order to improve social welfare and maintaining quality of physical, social and cultural aspect. Unfortunately, community empowerments often deal with a lot of problems, partly due to the lack of insight of local community about the importance of sustainable tourism management. The problems become more difficult when the community based tourism (CBT) program should applied in mountain based destination, with tight preservation function. The regulations of tourism development are tight, while the willingness of local community to participate as a part of tourism system is high. Therefore, some of the community empowerment program should be directed to the activities that support the program of sustainable tourism development. Regarding to this problem, the research was done to analyze the relationship between community's insight on sustainable tourism with their willingness to participate in sustainable development program. The hypothesis is people who have a good insight expected to participate in voluntary sustainable tourism development activities. The research was conduct in Ciwidey district, a popular mountain based destination in West Java, Indonesia. A questionnaire survey was conducted with 100 samples of local community who were identified through Slovin formula. The results indicate that there is a significant correlation between the variable of community insights on sustainable tourism with their participation $(\alpha=$ 0.02). It can be interpreted that the higher the public insight the higher the level of community participation. This research is related with the specific aspect of CBT's perception that dealing with individual decision to participate, rather than CBT's model development as previous researches. The result of this research is utilitarian in building other CBT program in mountain based destination, especially in preserving the quality of nature environment.
\end{abstract}

Keywords- CBT, community participation, mountain based destination

\section{INTRODUCTION}

The presences of community who live side by side with forest area, has become a part of forest management system. The interaction between community and forest as the source of their livelihood has influence forest continuity. Regarding to forest recreation management, the local community empowerment becomes one of efforts to increase local prosperity and knowledge, especially about forest function as conservation, preservation and tourism destination. The community becomes a part of forest ecosystem, which could receive the impact of tourism activities surrounding them. The perception of local community is one of the key factor that influenced community participation to support sustainable tourism vision and mission, or even faster the process of forest destruction and demote the environment quality.

The development of nature based tourism in mountain region, eventually facing a complicated problems regarding to its preservation function and its role as wildlife habitat. In other side, the wildlife and physical landscape of mountain region become main attraction that attract visitor to visit. Therefore, the local community took this opportunity to participate in tourism development through local business management such as building lodging facilities, provide food and beverage for tourists, being a local guide, and others. Frequently, in operating the local business, the community is more focus on economic benefit and abandoning the decreased of environment quality as an impact of their tourism activities. They try to get closed to the core zone as the main attraction, and build some kiosks, ignoring the proper waste treatment, take out some protected vegetation or animals and others bad activities which decreasing the quality of nature environment (figure 1).

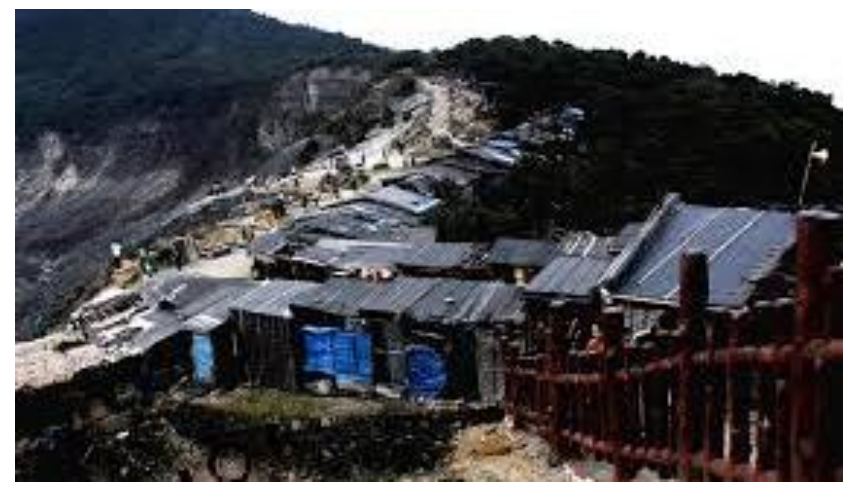

Fig. 1. Negative activities of local community in nature based destination

This research was conduct to analyze the correlation between community's perceptions with their willingness to participate in sustainable tourism management. The better understanding is alleged to be more respect in participation of some nature management program, included in preserve the environment voluntarily. Some researchers also showed that local people's insight and knowledge will influence the achievement of CBT program [2][8]. In the other side, the perception and 
knowledge are factors that influence the motivation and action in taking decision to participate in CBT's program. The alleged of this research is there is a high correlation between community's perceptions with their participation in community based tourism program.

If this hypothesis is proven, then the CBT program in Ciwidey region will firstly start with community awareness program through some training and counseling program about sustainable tourism, and after that the participation will voluntarily done by the community. The important of this research is regarding with the Ciwidey's land use as a preservation and conservation area, in which geographically the mountain region is very sensitive to some natural hazard. Moreover many local settlements are adjacent with the preservation area. The activities of local community also play an important role, whether its burden or proper with the land characteristic. This mountain region with many natural attractions for tourists needs to manage properly by collaboration between local community, government and private sector to meet its multifunction as tourism destination, preservation area, and residence for local community. This research is focused on community perception on their involvement in tourism management of mountain region, which is different with other research that more focused on building a model of CBT. Moreover the results of this research are beneficial to building CBT program in mountain based destination.

\section{LITERATURE REVIEW}

In the concept of sustainable tourism development, community involvement is known as Community Based Tourism (CBT). Many literatures state that CBT could strengthen communication and interaction between stakeholders, to gain mutual understanding, solidarity and productivity of tourism vision [6][9]. The community should be involved in every step of planning process and decision making in achieving sustainable tourism development. It cannot be denied that the development of tourism sector in Indonesia is highly related with the presence of local community who live side by side with tourism attraction.

However, the implementation of CBT concept is not an easy way. Theoretically, the sustainable tourism has an ideal achievement, beneficial for all stakeholders. In reality, involving the community with the planning process and management program need highly costs, such a long time and complicated process of community awareness [7]. Oftentimes this phenomenon always becomes a main problem in implementing CBT program. Stake holder awareness plays an important role to succeed sustainable tourism development. Many research showed about the gap between concept and implementation of CBT [4][11].

One of many factors determine the achievement of implementing sustainable tourism development concept is depend on how far the community are involved and aware with tourism vision in their region. The role of community involvement is well known and believed as key factor of sustainable development [10]. While the level of community participation is divided in to nonparticipation, some degree of external inducement of forces, active and direct citizen participation, and active agent of change, having ability to find solution to their problem, make decisions, implement actions and evaluate their solutions [12].

\section{METHODS}

The research was conducted in the District of Ciwidey, West Java, Indonesia, which is geographically located in 107031'30''WL- 107031'30'EL dan 07002'15'”NL 07018 '00' NL. Ciwidey District is a mountainous natural tourism region. The region has many natural tourist destinations types such as lakes, mountain landscapes, volcanic craters, natural forests and hot springs. The visiting level of the region is highly enough. In 2013, the visitation reached 737,363 tourists per year. From total areas of 40,674.67 Ha, almost $40 \%$ of them are protected areas that also have a tourism function. Within this area, there are 21 villages inhabited by local people who live directly adjacent to the natural tourism area. Their livelihood is on the tourism industry and agriculture fields. Environmental sustainability of the regions is determining the life quality of local people since it supplied water, oxygen, and other invaluable biodiversity.

There are two variables used in the research which are the locals' perception towards sustainable tourism concept (X) and willingness to participate in tourism management program (Y). Those two variables had been examined to see its relevance. The results used as a reference in determining the CBT program in the region. Variable indicators presented in Table 1.

TABLE I. LOCALS' PERSEPTION TOWARDS SUSTAINABLE TOURISM CONCEPT

\begin{tabular}{|c|c|c|c|}
\hline $\begin{array}{c}\text { Sub } \\
\text { Variable }\end{array}$ & Indicators & Score & Category \\
\hline \multirow[t]{4}{*}{$\begin{array}{l}\text { Tourism } \\
\text { and nature }\end{array}$} & $\begin{array}{l}\text { Preserve and integrate } \\
\text { environment }\end{array}$ & 4.17 & High \\
\hline & $\begin{array}{l}\text { Conserve nature and } \\
\text { biodiversity }\end{array}$ & 3.98 & High \\
\hline & $\begin{array}{l}\text { Apply environmentaly } \\
\text { friendly technology }\end{array}$ & 3.99 & High \\
\hline & $\begin{array}{l}\text { Interpretation program for } \\
\text { locals }\end{array}$ & 3.93 & High \\
\hline \multirow{3}{*}{$\begin{array}{l}\text { Tourism } \\
\text { and socio- } \\
\text { culture }\end{array}$} & $\begin{array}{l}\text { Preserve and integrate the } \\
\text { locals' culture }\end{array}$ & 4.13 & High \\
\hline & $\begin{array}{l}\text { Each stakeholder responsible } \\
\text { to the sustainable tourism } \\
\text { program }\end{array}$ & 3.91 & High \\
\hline & $\begin{array}{l}\text { Open access and information } \\
\text { on sustainable toursim for } \\
\text { local }\end{array}$ & 4.06 & High \\
\hline $\begin{array}{l}\text { Tourism } \\
\text { and local } \\
\text { economy }\end{array}$ & $\begin{array}{l}\text { Facilitate locals' products in } \\
\text { tourism development }\end{array}$ & 4.10 & High \\
\hline
\end{tabular}

The data were obtained in an ordinal scale. The scale described the degree of the very positive value to the very negative value, using a Likert scale. Data taken by closedended questionnaires with stratified random sampling approach. The sample size was refers to the Slovin formula, therefore the total number of respondents was 100 respondents of the local people which is living closed to the natural tourism area.

The main purpose of the research is to identify the causal relationship between the two variables. The significant effect of variable $\mathrm{X}$ to variable $\mathrm{Y}$ obtained through correlation analysis. It first began with normality test data using Kolmogorov-Smirnov Test at the 0.05 
significance level. After that, the correlation of the data was tested by Pearson Correlation Test at the 0.05 significance level. All of tests were performed by the software SPSS 20.

\section{RESULTS AND DISCUSSION}

\section{A. Level of Locals' Perception toward Sustainable Tourism Concept}

The results showed that the locals are having high knowledge of how the sustainable tourism should be done. They understood that tourism activities must be able to preserve the nature and local culture as well as improve the economic levels (Table I).

\section{B. Locals' Willingness to Participate in Tourism Management Program}

After the data tabulation and analysis performed to the questionnaires of locals, it is showed that the willingness of the locals to participate in the tourism management and development in Ciwidey are about of 3.59 (Table II). This value can be interpreted as the communities willing to participate on management process since there are some benefits for the locals to pursue. However, while we examined in more detail, the interest of the locals to participate in decision-making was lower than the other type of participation.

TABLE II. LOCALS' WILLINGNESS TO PARTICIPATE IN TOURISM MANGEMENT PROGRAM

\begin{tabular}{|c|c|c|c|}
\hline $\begin{array}{l}\text { Sub } \\
\text { Variabel }\end{array}$ & Indicators & Score & Category \\
\hline \multirow{3}{*}{$\begin{array}{l}\text { Participation } \\
\text { in decision } \\
\text { making }\end{array}$} & $\begin{array}{l}\text { Participation in tourism } \\
\text { planning }\end{array}$ & 3.26 & Enough \\
\hline & $\begin{array}{l}\text { Participation in giving } \\
\text { solution for development } \\
\text { problem }\end{array}$ & 3.10 & Enough \\
\hline & $\begin{array}{l}\text { Participation in decision } \\
\text { making }\end{array}$ & 2.98 & Enough \\
\hline \multirow[t]{3}{*}{$\begin{array}{l}\text { Participation } \\
\text { in actuating }\end{array}$} & $\begin{array}{l}\text { Participation in development } \\
\text { tourist attraction }\end{array}$ & 3.62 & High \\
\hline & $\begin{array}{l}\text { Participation in maintaining } \\
\text { environmental balance }\end{array}$ & 3.60 & High \\
\hline & $\begin{array}{l}\text { Participation in maintaining } \\
\text { cleanliness and beauty of } \\
\text { area }\end{array}$ & 3.93 & High \\
\hline \multirow[t]{3}{*}{$\begin{array}{l}\text { Participation } \\
\text { in utilizing }\end{array}$} & $\begin{array}{l}\text { Participation in tourism } \\
\text { business }\end{array}$ & 3.45 & High \\
\hline & $\begin{array}{l}\text { Participation in getting } \\
\text { employment in tourism }\end{array}$ & 3.80 & High \\
\hline & $\begin{array}{l}\text { Participation in various } \\
\text { supporting business of } \\
\text { tourism }\end{array}$ & 3.92 & High \\
\hline \multirow{3}{*}{$\begin{array}{l}\text { Participation } \\
\text { in } \\
\text { examining }\end{array}$} & $\begin{array}{l}\text { Participation in evaluating } \\
\text { the business }\end{array}$ & 3.79 & High \\
\hline & $\begin{array}{l}\text { Participation in evaluating } \\
\text { the development of common } \\
\text { means }\end{array}$ & 3.48 & High \\
\hline & $\begin{array}{l}\text { Participation in evaluating } \\
\text { independency of community }\end{array}$ & 3.81 & High \\
\hline
\end{tabular}

\section{Correlation between Locals' Perception and Locals' Willingness to Participate in Tourism Management in Natural Tourists Attraction Area}

In the CBT program, theoretically, the level of locals' perception has an influence on the level of locals' participation in tourism management, which means that the higher the knowledge, the higher the local will participate in sustainable tourism management. In this research, before continuing to the level of influence, the obtained data has been performed with KolmogorovSmirnov test. The test showed the level of data significance is $0.065>0.05 \alpha$ value. It indicated obtained data are distributed normally and can be proceed to the correlation test.

Since it was important to see the correlation between two variables, the Pearson Correlation test has been done to look at the influence of the locals' perception to the locals' willingness to participate. As our first hypothesis, there is a correlation between those two variables. Indeed, the correlation was significance at the level of $\alpha$ value 0.05 , with the p-value 0.002 . Hence the value itself formed in a positive correlation, we interpreted that the higher the locals' perception towards sustainable tourism, the higher the locals willingness to participate in the process of tourism management on natural attraction.

Correlation test results prove the hypothesis that the level of locals' perception affects the level of their participation. Thus the CBT program in natural tourist attraction areas, in this case Ciwidey, should be begin with the process of improve the public awareness through training and counseling on sustainable tourism. Thereafter, participation would present itself through public awareness, and without any doubt, community participation can reduce the negative impacts of tourism activity through collaboration and development agreement [5].

To see which factors is most influence on the level of participation, then the analysis factor was performed to the variables of locals' perception. In Kaiser-Meyer-Olkin (KMO) and Bartlett's Test, the desired value for the test was higher than 0.5 with research significance 0.05 with KMO value are 0.858 , which means higher than the parameters with the significance of 0.000 . The value allowed us to continue with the further stage of analysis, which is Measure of Sampling Adequacy (MSA) test.

Based on the MSA test, all the independent variables can be analyzed further for their each value are higher than 0.5. Table III describes the communality value which is explain the most influence factors of the locals in participating on natural tourist areas management.

\section{TABLE III. COMMUNALITY VALUE OF INDICATOR VARIABLE}

\begin{tabular}{|c|c|c|}
\hline Variable & Initial & action \\
\hline Preserve and integrate environment & 1.000 & 0.525 \\
\hline Conserve nature and biodiversity & 1.000 & 0.521 \\
\hline $\begin{array}{l}\text { Facilitate locals' products in tourism } \\
\text { development }\end{array}$ & 1.000 & 0.749 \\
\hline
\end{tabular}

The results showed that the level of local perception related to sustainable tourism concept is good. People understand that tourism activities must be able to preserve the natural environment, maintain the integrity of the local culture and increase local incomes. Meanwhile, in the aspect of participation, people have high participation willingness at the implementation stage, utilization and assessment results, but feel less motivated to participate in the planning stage. Several previous studies have stated that the knowledge and insights of people can affect 
participation levels associated with the concept they understands [8]. A good knowledge in sustainable tourism concept is making good awareness to participate in the sustainable tourism management in the study area.

A strong relationship between the locals' insight into the level of participation, has also been widely described in previous studies [2][8]. The contrast finding to other studies is the reluctance of local to participate in the planning aspects. This may happen due to facilitation lack of their opinion in determining regional policy. Planning nature tourism area is still top-down process, it's only determined by academics studies or the central government, without giving any feed back to the locals to jointly participate in defining the rules for their own territory. Oftentimes, people are not involved in determining the vision, mission and not accommodated to bringing out the local rules. Community groups with little power, often defeated by the will and opinions of elites groups that close to government [1][6].

The utilization aspect of local products is a component that has the most powerful influences that motivate locals to participate in the management of sustainable tourism. Society want the empowerment of local products to be appointed as the main component in the development of tourism, such as local cuisine, handicrafts, utensils and ornaments of buildings as well as other local components. Besides, the empowerment of local products can elevate the identity of the region, making it a unique tourist attraction, which sets it apart from other destinations. With the appointment of local products and local culture as a tourist attraction, then the locals will seek to learn, to train the younger generation to understand and good at it, and finally to love and preserve its culture. Development of local products in the community development programs should be directed at strengthening the local identity through the incorporation of natural elements, culture, customs traditions, and local wisdom. This integrated concept is expected to create a strong brand and unique destinations, encouraging work opportunities for local people, improve their skills and to improve the general welfare of society. In this case, the cooperative understanding between the locals and government, creative community, and academia are need to be done to provide additional training and skills for community, including in improving people's creativity in packaging a variety of local products.

Community insights related to natural environment has also become a powerful factor affecting community participation. Tourist activities those are able to give satisfaction to locals, provide protection against natural, cultural and social life, maintain economic stability and provide benefits to all involved stakeholders, are being the key to the success of sustainable tourism program [3]. The community empowerment concept should be able to improve the economic quality of the locals, to support the conservation of natural and cultural environment, improved quality of life, and strengthening the capacity of locals to be able to meet the needs of the present and future dating [6][9].

The sustainable tourism development concept in the natural area with protection functions are reflected in three main programs, namely: the nature protection program, community involvement programs and tours program. Tourist activities should be directed to responsible tourism activity form, education-charged based natural and cultural environment.

\section{CONCLUSION}

In this study related to the correlation between the public insight and the level of locals' participation in tours have produced something quite enlightening. We can report that there is a relationship between two variables. Significant relationships have been identified through analysis of Pearson correlation. It can be interpreted that the higher the public insight the higher the level of community participation. The contrast result with other study shown by the less willingness of locals to participate in the decision making process. With these findings, the development of community-based tourism in natural tourist areas can be start through approaches that we have formulated. The approach begins with how to stimulate and transfer the knowledge and insight to the local community about the importance of environmental protection and culture. The next step is how to improving the economy of society through business activities based on local creativity. As at the end stage is to preserve the traditions of indigenous cultures and positive through the strengthening of local identity. The result of this research is utilitarian in build up CBT program in mountain-based destination, especially in preserving the quality of nature environment.

\section{REFERENCES}

[1] Blackstock,K (2005). A critical look at community based tourism. Community Development Journal, 40(1), 39-49

[2] Cole,S. (2006). Information and empowerment : The key to achieving sustainable tourism. Journal of Sustainable Tourism, 14 (), 629-644.

[3] Edgell, D.L. (2006). Managing sustainable tourism : A legacy for the future. Binghamton, NY:Haworth Press.

[4] Garrod,B., \& Fyall,A. (1999). Beyond the rhetoric of sustainable tourism? Tourism Management, 19(3), 199-212.

[5] Jamal, T.B., \& Getz, D. (1995). Collaboration Theory and community tourism planning. Annals of Tourism Research, 22(1), 186-204.

[6] Kontogeorgopoulos, N. (2005) Community-based tourism in Phuket and Ao Phangnga, Thailand : Partial victories and bittersweet remedies. Journal of Sustainable Tourism, 12(1). 4-23.

[7] Ladkin,A., \& Betramini, A.M. (2002). Collaborative tourism planning : A case study of Cusco, Peru. Current Issues in Tourism, 5(2), 71-93.

[8] Manyara, G., \& Jones, E. (2007). Community-based tourism enterprises in Kenya: an exploration of their potential as avenues of poverty reduction. Journal of Sustainable Tourism, 15(6), 628644.

[9] McMinn. S. (1997). The challenge of sustainable tourism. The Environmentalist, 17(2), 135-141.

[10] Murphy,P.E. (1985). Tourism : A community approach. New York, NY: Methuen.

[11] Sharpley, R. (2000). Tourism and Sustainable Development: Exploring the Theoritical devide. Journal of Sustainable Development, 8(1), 1-19.

[12] Tosun, C. (2006). Expected nature of community participation in tourism development. Tourism Management, 27(3), 493-504. 